\title{
Plague reservoir species throughout the world
}

\begin{abstract}
.
Plague is known since ancient history, as a re-emerging infectious disease, causing considerable socioeconomic burden in regional hotspots. To better understand the epidemiological cycle of the causative agent of the plague, its potential occurrence and possible future dispersion, one must carefully consider the taxonomy, distribution, and ecological requirements of reservoirspecies in relation either to natural or human driven changes (e.g. climate change, urbanization). In recent years, the depth of knowledge on species taxonomy and species composition in different landscapes has undergone a dramatic expansion, driven by modern taxonomic methods such as synthetic surveys that take into consideration morphology, genetics and the ecological setting of captured animals to establish their species identities. Here we consider the recent taxonomic changes of the rodent species in known plague reservoirs and detail their distribution across the world, with a particular focus on those rodents considered to be keystone host species. A complete checklist of all known plague-infectable vertebrates living in plague reservoirs is provided as an appendix.
\end{abstract}

Key words: Plague, reservoirs, mammals, rodents, taxonomy

Introduction

Zoonotic diseases surveillance always benefits much from precise taxonomy of the reservoirs/vectors. With a deep taxonomic knowledge on Anopheles gambiae complex species, the main vector for malaria with significant human health burden, control measures have been slanted towards on human-specific malarial vectors (Besansky 1999; Bickford et al. 2007). Adequate treatment for man suffering from Leishmaniases, and effective control measures need an update taxonomy for parasites and the reservoirs (Ramírez et al. 2016). We will make the case that a similar improvement in the taxonomy of plague-infected small mammal species, as presented here, offers similar opportunities. We will first present an overview of the relevant dynamics, small mammal species and human interactions of plague ecosystems.

Plague is a contagious disease caused by the gram-negative enterobacteria Yersinia pestis. This bacterium has been responsible for mass human mortality in Eurasia and Africa (Gage \& Kosoy 2005). Particularly devastating was the Second Plague Pandemic known as 'Black Death' which started in Central Asia in 1346 and subsequently circulated across Eurasia and Africa until it transitioned into the Third Pandemic in the $18^{\text {th }}$ century (DeWitte 2014; Sticker 1908; Benedict 
1996; Green 2018; Chouin 2018). Plague however has been present in human population for much longer. The oldest DNA confirmed flea-borne bubonic strain of the pathogen is from 3800-year-old skeletal remains (Spyrou et al. 2018), while less pathogenic lineages have been discovered as far back as 6000 years ago (Rasmussen et al. 2015; Rascovan et al. 2019). Plague is still found in many Asian, African and North and South American countries, and causes a modest number of fatal infections every year (Bertherat 2019). Since 1954 the number of annually reported infections with $Y$. pestis has fluctuated between $\sim 100-3000$ cases, with 100200 fatalities (Bertherat 2019).

Plague is a predominantly zoonotic disease circulated in natural plague foci as the rodent host flea vector- $Y$. pestis system. Humans are an incidental and highly susceptible host at risk of infection particularly when the disease spills over during epizootic periods in wildlife plague reservoirs (Stenseth et al. 2008; Samia et al. 2011).

\section{Current distribution of plague foci}

Plague foci naturally occur in xeric regions between $49^{\circ}-51^{\circ}$ northern latitude and $34^{\circ}-37^{\circ}$ southern latitude (see Figure 1). The realized niche of plague foci has been strongly shaped by long-distance commercial trade across the centuries (Rascovan et al. 2019; Xu et al. 2019; Namouchi et al. 2018) and by landscape alterations (deforestation, desertification, overgrazing, and other agricultural activities) that brought humans and zoonoses reservoirs/vectors into close contact (Keesing et al. 2010; Lambin et al. 2010), and by large-scale interventions aimed at locally controlling or eradicating plague foci (Jones et al. 2019).

On a local scale, the realization of plague foci, and their dispersal on a more regional scale is associated with the biological (predators, vegetation, rodents, vectors, and the bacterium) and environmental factors (climate and elevation); such as the intensity of rodent migration during periods of overcrowding (McNeill 1979; Gage 2010), extended phenotype adaptation by the pathogen to a scarcity in vectors (Cui et al. 2020), and by the transport of the pathogen by predatory birds or mammals (Burdelov 1991; Poland \& Barnes 1979). Human activity also plays a role on this regional scale of plague activity and dispersal. For instance, in Tanzania, the risk of plague infections among rodents is correlated to agricultural practices which affect reservoir density (McCauley et al. 2015).

Persistence of Yersinia pestis in natural foci 
Plague foci can exist in a quiescent, enzoonotic, or epizootic state, depending on the host and flea vector species that occur in the ecosystem, their abundance, and other properties of the ecosystem itself. In the quiescent state, no cases are reported in humans and (providing the surveillance system exists) no cases are detected in rodents for an extended period of time. During the quiescent state, which can last decades, plague can be telluric (bacteria survive in the soil of the infected host burrows) (Baltazard et al. 1960; Boegler et al. 2012; Benavides-Montaño \& Vadyvaloo 2017; Barbieri et al. 2020), or circulate in low intensity in small microfoci among "preserver" or "resistant" reservoir hosts. These microfoci are not picked up by chance or inaccessibility (Fedorov 1994; Stenseth et al. 2008; Ramasindrazana et al. 2017). The exact mechanism by which plague persists within preserver hosts during quiescent phase has not been fully elucidated. Several components are thought to be important, including a high resistance heterogeneity of the host (Eisen \& Gage 2009), presence of a flea species which allows for the dormancy of plague within them (off-host fleas) (Gage \& Kosoy 2005; Bazanova et al. 2007), and possibly also the ability of a reservoir species to reacquire the bacterium from plaguecontaminated soil (Karimi 1963; Ayyadurai et al. 2008; Malek et al. 2017), when climatic conditions are favorable (Eisen et al. 2008a; Lowell et al. 2015).

A plague focus is in the enzoonotic phase when $Y$. pestis is regularly detected, but in low frequency (generally < 2\% of rodents captured) (Davis et al. 2004; Xu et al. 2015). During the enzoonotic phase, plague is assumed to persist by being passed on between preserver hosts, or via meta-population turnover, where subpopulations replace one another during inter-epizootics periods (George et al. 2013). In other words, the role of an extirpated carrier can be assumed by another, hence ensuring the persistence of $Y$. pestis over extended periods. Whether a particular plague focus is classified as quiescent or as a low intensity enzoonotic phase is to some degree subjective and depends on the intensity of plague surveillance program.

The third stage is an epizootic cycle, i.e. an epidemic of plague among the rodents in the plague focus. Typically, there are three prerequisites for an epizootic cycle to occur. Firstly, the ecosystem needs to harbor a sufficient numbers of hosts that are highly sensitive to plague, which, when infected, generate a high levels of bacteremia in their blood. Secondly, a sufficient number of fleas must be present to transmit the infection between rodent hosts (Hinnebusch 2005, Reijniers et al. 2012). Finally, the plague bacterium should be in a non-telluric state, present in at least some of the rodent species in the ecosystem. 


\section{Three key roles of rodents within a plague focus}

Yersinia pestis circulation within natural foci is thought to be guaranteed through three processes: preservation, accumulation, and dissemination (Burdelov 1991). Rodents are integral to all three of these processes. Preservation of the pathogen occurs through primary rodent hosts that are consistently present in the region, and generally experience low or heterogeneous levels of bacteremia when infected. Accumulation of the pathogen in the ecosystem occurs through secondary or tertiary rodent hosts which acquire $Y$. pestis from the primary or secondary hosts. The transmission is always mediated by fleas. The secondary and tertiary rodent hosts are typically highly sensitive to the pathogen and cause the disease to become more prevalent in the ecosystem. This creates a danger of spillover to other species (Gage 2010; Zeppelini et al. 2016). The dissemination happens particularly at times of rodent overcrowding, when the animals, especially the weaning juveniles, disperse towards vacant territories, providing the opportunity for spreading of the pathogen (Gage 2010). The burrow-dwelling infected fleas that remain active within a burrow after its rodent occupants have died, can convey the infection to its new dwellers. Plague-infected fleas can also be picked up by birds or mammals that prey on rodents may act as disseminator hosts, either by transporting plague-infected fleas to new regions, or by becoming infected themselves after consuming plague-infected prey (Burdelov 1991; Poland \& Barnes 1979; Salkeld \& Stapp 2006, Salkeld et al. 2007).

The interface between human communities and plague reservoirs can be permanent (like in synanthropic reservoirs- e.g. the epidemic in Madagascar in 2017), or dynamic- such as when plague reservoirs expand into urban communities or humans encroach upon existing wildlife reservoirs- (e.g. the plague outbreak in Los Angeles in 1924-1925 or the epidemic in Kurdistan (Iran) in the early 1940s which both were driven by infected rodents invaded to human communities) (Baltazard et al. 1960; Caten \& Kartman 1968; Kool \& Weinstein 2005; Randremanana et al. 2019).

\section{The role of rodent taxonomy in understanding plague ecology}

Three taxonomy-related factors play a particularly important role in understanding plague ecosystems - (1) the ecological and genetic characteristics of the present rodent host species, (2) species-tailored sampling and surveillance methodology, as well as (3) the impact of plague on conservation efforts on particular species. 
First, a precise taxonomic identification based on systematic surveys (Zeppelini et al. 2016) is crucial to improve our ability to carefully extrapolate genetic and ecological traits of rodent species to for which we lack specific knowledge to closely related species which are better studied with regard to plague. This will allow us to understand the roles that different local rodent species may play (preserver, amplifier, disseminator) in a local plague ecosystem, evidence for plague resistance based on particular genes and gene families (Nilsson et al. 2020; Busch et al. 2013; Tollenaere et al. 2011; Andrianaivoarimanana et al. 2018), or the likelihood that the blood of a local rodent species is of the type that greatly facilitates the capacity of fleas to act as an efficient vector of plague (recent experimental work by Eisen et al. (2008b) and Bland et al. (2018), currently limited to only a few species). In all cases, having a taxonomically and genetically updated list of rodent hosts of plague ecosystems allows for careful extrapolation of these results across a wider range of species. Second, a more in-depth zoological knowledge of the reservoirs will affect sampling activities in foci during or after epizootics. Most plague surveillance done in urbanized areas employs methods that enhance the capture of certain taxa but exclude others (Moore et al. 2015; Zeppelini et al. 2016). A refined taxonomic list facilitates a more sound allocation of usually limited resources (Jones et al. 2019). Finally, the impact plague has on species which are of conservation concern is gaining attention (Biggins \& Kosoy 2001a,b). For instance, plague epizootics cause significant reduction on the population size and heterogeneity of Cynomys spp., directly (cf. Trudeau et al. 2004), and on their key predator (Mustela nigripes) indirectly (Biggins \& Godbey 2003; Matchett et al. 2010). Exact identification of hosts, their distribution and habitat demands is both a critical conservation objective and a public health priority.

\section{Recent improvements in taxonomy}

New and powerful techniques in taxonomy (e.g., single/multiple gene analyses, next generation sequencing (NGS), genome wide association studies (GWAS), ecological niche modeling (ENM), and geometric morphometrics) have led to considerable development in host and pathogen species delimitation, which altered their taxonomic ranks and exposed cryptic species richness (e.g. Lecompte et al. 2008 Pečnikar \& Buzan 2014; Meinel et al. 2014; Bonnet et al. 2014; Purty \& Chatterjee 2016; Fan et al. 2017; Colabella et al. 2018; Fan et al. 2018). Indeed, molecular techniques have profoundly changed our understanding of diversity by splitting species defined by morphology into several species with own evolutionary history (Zachos et al. 
2013, 2020; Taylor et al. 2019). In a similar way, population genetic analyses of pathogen species are of prime importance in detecting possible cryptic species and revealing the processes that underline their evolution (Brown et al. 2013).

The management of many emerging infectious diseases will certainly facilitate by better understanding of the types of species form reservoirs (Plourde et al. 2017). The identification of sibling and cryptic species, as well as of molecular lineages and morphological variants which associate with zoonotic diseases is highly relevant for both wildlife conservation policy, management of host/pathogen populations. In a recent review of South American plague reservoirs, 22 of 50 rodent hosts of $Y$. pestis were found to have undergone taxonomic changes over the last 20 years (Bonvicino et al. 2015). Most recently, another contribution was also performed to associate previously published information of plague reservoirs and taxonomic dynamics in Brazilian foci (Fernandes et al. 2020). Such researches are highlighting the urgent need for a global update of the taxonomy of rodent species living in plague foci. Available lists are either limited in geographic scope (Bonvicino et al. 2015), taxonomically outdated (Pollitzer 1960; Gratz 1999), or incomplete in their description of the systematic methodology used (Sludskyi 2014b; Dubyanskiy \& Yeszhanov 2016). Different species, as well as different populations of particular species show a variance in susceptibility, mortality, and life history, they might play a different role in plague epidemiological cycles. As a result, precise taxonomic identification is of the utmost importance and demands systematic surveys to avoid biases (Zeppelini et al. 2016).

In this study, we aim to update the current information on worldwide plague reservoirs in order to improve future plague preparedness and surveillance programs. For this purpose, we will provide a taxonomically updated global list of both the "preserver" rodent hosts living in plague foci, as well as all other plague-sensitive rodents living within these foci.

\section{Materials and Methods}

In this review, an up-to-date taxonomic list of the vertebrate fauna of the plague reservoirs are provided considering the available literature indexed in Google Scholar, NCBI's PubMed, Science Direct, World Health Organization manuals up to June 2020 (e.g. Davis 1953; Pollitzer 1960; Hudson et al. 1964; Marshall et al. 1967; Lechleitner et al. 1968; Warsawskiy et al. 1971; Klein et al. 1975; Turner et al. 1975; Twigg 1978; Nelson 1980; Clover et al. 1989; Henke et al. 1990; Dyer \& Huffman 1999; Gratz 1999; Kozlov \& Sultanov 2000; Fukushima et al. 2001; 
Karimova \& Neronov 2007; Salkeld et al. 2007; Edmunds et al. 2008; Chen et al. 2009; Riehm et al. 2011; Saraev \& Sklyarenko 2012; Ziwa et al. 2013; Martin-Alonso et al. 2014; Sludskyi 2014a,b Bonvicino et al. 2015; Malek et al. 2016; Dubyanskiy \& Yeszhanov 2016). Moreover, to cover all the related works properly, different combinations of keywords were used for our search such as "Wildlife Plague", "Plague, epizootic/enzootic periods", "Plague, Reservoirs, Rodents", "Plague, Reservoirs, Small mammals", "Plague History", "Yersinia pestis, Reservoirs, Wildlife", "Plague outbreaks", "Plague, Reservoirs, Taxonomy", Rodent-borne Diseases, Reservoirs". The references found in the selected articles were studied to increase the scope of the search and cover as many articles as possible. The next step was a taxonomic update of the known species, taking into account the recent taxonomic dynamics in zoological literature. The "Handbook of the Mammals of the World (Wilson et al. 2016, 2017)" series were considered to be the principal foundations but compiled with the information available from the International Union for Conservation of Nature (IUCN), and the Integrated Taxonomic Information System (ITIS) (Tom \& Dave 2019). Furthermore, recent changes in available publications up to June 2020 were screened (e.g. Miura et al. 2006; Kryštufek \& Vohralik 2012; Kitchener et al. 2017; Lebedev et al. 2018; Bannikova et al. 2019; Mahmoudi et al. 2020). Finally, unintended spelling errors in previous lists (Sludskyi 2014b; Dubyanskiy \& Yeszhanov 2016) were corrected. Extracted list of reservoirs were classified into their taxonomic orders, and a chi-squared test was performed between the observed distribution and the true distribution of species among mammalian orders to determine whether plague reservoir species are special or the infection has been taken erratically.

Finally, the distribution data of each species was collected from the range data on the website of IUCN Red List (https://www.iucnredlist.org/). Taking into account the Handbook of the Mammals of the World (Wilson et al. 2016, 2017) and recent taxonomic re-arrangements, several incorrect spellings and outdated taxonomy were observed for the reported reservoirs on the IUCN website (last updated November, 2019). For instance, Pygerethmus platyurus, emended to Pygeretmus platyurus; Paradoxurus hermaphrodites to Paradoxurus hermaphroditus, and Cavia porcella is corrected to Cavia porcellus. Species which were listed under their previous taxonomy on the IUCN website were also taken into consideration beneath their most current taxonomy. The global figure of plague reservoir species-richness was performed using the emended taxonomy presented in this manuscript (Figure 2). 


\section{Discussion}

The list of reservoirs provided in the present study combined the assembled works by Sludskyi (2014b), Bonvicino et al. (2015), and Dubyanskiy \& Yeszhanov (2016) with subsequent additions found in our extensive review of literature published up to June 2020 (see, Appendix Table). Compared to previous taxonomic collections of reservoir plague hosts, this work adds 15 species, thus resulting in a total of 351 species of mammals. We highlight $\geq 47$ species (13.35\%) that can act as known primary hosts of plague around the world; 25 among these species are resistant (such as Meriones persicus and M. libycus in Iranian-Kurdistan focus), while 22 are considered susceptible (such as Meriones vinogradovi and M. tristrami from the Pre-Araksinsky low mountain (Azerbaijan, Armenia) and Iranian Kurdistan foci, cf. Baltazard et al. 1960; Emelyanov 1974) (for a species richness map and complete list of resistant and susceptible reservoirs at the global scale cf. Table 2 and Figure 3). However, one should take into account that the list of preserver and amplifier hosts are not fully understood, and require further investigation (e.g. experimental inoculation). 108 taxonomic names were updated to their most current status (either synonymous alterations or inter-generic/family translocations) and 15 alternative/misspellings of species names were corrected. Taxonomic and distributional notes are linked to the host species with dynamic or uncertain affinity and questionable distributions (cf. Appendix).

Identified reservoir species belong to eleven orders: Scandentia (1 species), Hyracoidea (1 species), Afrosoricida (1 species), Didelphimorphia (2 species), Primates (2 species), Artiodactyla (7 species), Eulipotyphla (13 species), Lagomorpha (14 species), Carnivora (31 species), and Rodentia (279 species). Wild birds, order Passeriformes (3 species), can also be contaminated with plague. It is clear that the species living within plague reservoirs and infected by plague are heavily slanted towards the Rodentia, Lagomorpha, and Carnivora. Comparison of the observed and expected distribution of mammalian orders among reservoirs were statistically significant considering the number of species in each mammalian order (Pearson's chi-squared test, $\chi^{2}=27.042, p=0.001$ ) (Table 1 ). This finding points on the characteristics of the plague reservoirs. Rodents and lagomorphs are usually the most specious and abundant in majority of ecosystems, their high birth rate yield a large number of naïve host individuals (Plourde et al. 2017). Other mammalian orders, mainly with slower life history, low reproduction output and species composition, are either absent from plague foci, less effective as reservoirs or carriers, or 
simply understudied. Carnivores are exception, as they are highly mobile, consume mainly small mammals (e.g. rodents and lagomorphs) which put them at high risk for the infection. Most birds, reptiles, and amphibians are thought to be resistant to $Y$. pestis infection (Gage \& Kosoy 2005), limiting plague predominantly to mammalian hosts and their ectoparasites.

Virtually any mammal can be infected by $Y$. pestis and may take part in the dynamic of infection between wildlife and humans, either as the main or incidental host of plague. However, the major vertebrate hosts in most primary foci are certain rodents (Table 2). Actually, it seems that diseases reservoirs are special in many aspects (cf. Plourde et al. 2017). Rodents are the most successful of all mammalian orders in terms of species number, have a worldwide distribution (excluding Antarctica), and are major components of nearly every terrestrial fauna (Kryštufek $e t$ al. 2005). They encompass 2552 extant species, i.e. $39.3 \%$ of the mammalian total species richness (Burgin et al. 2018). Their adaptability to a wide variety of lifestyles (e.g. arboreal, subterranean, semi-aquatic etc.), environments (e.g. urban, desert, and sylvatic biotopes), their high reproductive output and rapid population turnover render them highly permissible amplification agents of zoonotic pathogens (Han et al. 2015). Mammals are considered the main source of novel human pathogens, and rodents are the mammalian order from which the highest number of known pathogen species have thus far been isolated (Woolhouse \& Gaunt 2007; White \& Razgour 2020). Indeed, fast-lived mammalian species tend to have higher reservoir competence for human pathogens (Brunner et al. 2008; Han et al. 2015). Rodents are by far the dominant carrier host of $Y$. pestis, alike for many other human pathogens (Plourde et al. 2017). As of now, 279 species of rodents have been identified as plague carriers, and the majority of them are from the superfamily Muroidea, specifically from the families Muridae and Cricetidae with 91 and 88 species, respectively. The complete list of the reservoirs and (a) related region(s) can be found in the Appendix.

A high level of rodent diversity within an ecosystem increases the translocation of plague between different reservoir hosts, prevents its local extinction, provides refuge for its survival, and facilitates pathogen dissemination (Ostfeld \& Keesing 2000; Snall et al. 2008; Laudisoit et al. 2009; Dunn et al. 2010). For plague, we see a positive association between species richness with the occurrence of plague and the intensity of plague outbreaks (Bonvicino et al. 2015; Sun et al. 2019). Such a relationship with species richness appears to be a general feature of disease 
ecology (Mollentze \& Streicker 2020), and highlights the value of good regional taxonomic profiles in estimating outbreak risks.

Plotting ranges of the plague-infectable species on maps clearly shows that only the presence of plague-infectable hosts, regardless of whether they are reservoirs or potential carriers (cf. Figures 2 and 3) is not a good predictor of the global spread of plague foci. For example, the map on Figure 2 exposes a high concentration of potential reservoirs in Europe where no known plague foci currently exist, although they are speculated to have existed in the past, based on historical and phylogenetic analyses (Carmichael 2016; Bos et al. 2016). Other conditions are also needed for the pathogen to survive and effectively circulate in the ecosystem. These conditions have not yet been established, but possibly retained in the soil following the death of the infected hosts (Baltazard et al. 1960; Eisen et al. 2008) in which rodent burrows are being explored (Karimova \& Neronov 2007; Malek et al. 2017; Spyrou et al. 2019; Barbieri et al. 2020). Species richness maps of potential hosts therefore should be considered with caution. The IUCN Red List, while frequently used (e.g. Han et al. 2015), is not of indispensable quality and gives an impression of the species richness distribution of plague hosts, rather than an absolute resource. For example, on the map, Madagascar lacks any plague hosts, while there are at least three species of rodents which have been experimentally confirmed to be plague-infected on the island (Rahelinirina et al. 2017). Furthermore, previous studies have already demonstrated that several other non-rodent species (Setifer setosus, Tenrec ecaudatus and Hemicintetes sp.) (Migliani et al. 2001; Richard et al. 2015) have been found seropositive or infected to plague on Madagascar, but their role in plague epidemiology are still under considerations through ongoing studies.

\section{Conclusion}

Recent developments in species delimitation and rearrangements of mammalian systematics have altered the taxonomic ranks of many groups. Cryptic species richness was exposed, previous morphospecies were split up into groups of closely related species, or were species moved from one taxonomic group to another (e.g. Lecompte et al. 2008; Zachos et al. 2013; Meinel et al. 2014; Bonnet et al. 2014; Pečnikar \& Buzan 2014; Purty \& Chatterjee 2016; Fan et al. 2017; Colabella et al. 2018; Fan et al. 2018; Taylor et al. 2019; Zachos et al. 2020). Such large taxonomic developments warrant a close re-examination of known plague reservoirs species (e.g. Bonvicino et al. 2015), particularly because -with few taxonomists involved in historic plague research-, plague host species have frequently been traditional identified only by 
morphological traits. Such an approach may be misleading, especially in cases of sibling/cryptic/closely related species or different geographic lineages. Because different species might respond to control measures differently, a precise species identification (both for pathogens and host) is of fundamental importance in understanding zoonotic disease epidemiology, control practices, and prevention of outbreaks (Bickford et al. 2007). Our updated taxonomy of plague reservoir species integrates a large number of taxonomic changes and corrects earlier misclassified species among previously identified reservoirs. Such a curated list opens up the possibility for interdisciplinary researchers to combine genomic, laboratory and field observations of plague more effectively to understand the epidemiological cycle of plague, and to improve local surveillance based on the local species composition.

\section{Conflict of interest}

The authors declare that there is no conflict of interest regarding the publication of this article.

\section{References}

Andrianaivoarimanana V, Rajerison M, Jambou R (2018). Exposure to Yersinia pestis increases resistance to plague in black rats and modulates transmission in Madagascar. BMC Research Notes, 11(1), 898.

Ayyadurai S, Houhamdi L, Lepidi H, Nappez C, Raoult D, Drancourt M (2008). Long-term persistence of virulent Yersinia pestis in soil. Microbiology, 154(9), 2865-2871.

Baltazard M, Bahmanyar M, Mofidi C, Seydian B (1952). Le foyer de peste du Kurdistan. Bulletin of the World Health Organization, 5(4), 441.

Baltazard M, Bahmanyar M, Mostachfi P, Eftekhari M, Mofidi C (1960). Recherches sur la peste en Iran. Bulletin of the World Health Organization, 23, 141.

Bannikova A, Lebedev V, Dubrovskaya A et al. (2019). Genetic evidence for several cryptic species within the Scarturus elater species complex (Rodentia: Dipodoidea): when cryptic species are really cryptic. Biological Journal of the Linnean Society, 126, 16-39.

Barbieri R, Texier G, Keller C, Drancourt M (2020). Soil salinity and aridity specify plague foci in the United States of America. Scientific Reports, 10(1), 1-9.

Bazanova LP, Nikitin AY, Popkov AF, Maevskii MP (2007). Seasonal dynamics of epizootic process of the plague agent Yersinia pestis transmission to the long-tailed suslik Citellus 
undulatus by the flea Citellophilus tesquorum in Tuva. Entomological Review, 87(6), 685-91.

Benavides-Montaño JA, Vadyvaloo V (2017). Yersinia pestis resists predation by Acanthamoeba castellanii and exhibits prolonged intracellular survival. Applied and Environmental Microbiology, 83(13). https://doi.org/10.1128/AEM.00593-17.

Benedict CA (1996). Bubonic Plague in Nineteenth-Century China. Vol. 14. Stanford University Press.

Bertherat E (2019). Plague around the world in 2019. Weekly Epidemiological Record, 25: 289292.

Besansky NJ (1999). Complexities in the analysis of cryptic taxa within the genus Anopheles. Parassitologia, 41(1-3), 97-100.

Bickford D, Lohman DJ, Sodhi NS et al. (2007). Cryptic species as a window on diversity and conservation. Trends in Ecology \& Evolution, 22, 148-155.

Biggins DE, Godbey JL (2003). Challenges to reestablishment of free-ranging populations of black-footed ferrets. Comptes Rendus Biologies, 326, 104-111.

Biggins DE, Kosoy MY (2001a). Influences of introduced plague on North American mammals -implications from ecology of plague in Asia: Journal of Mammalogy, 82, 906-916.

Biggins DE, Kosoy MY (2001b). Disruptions of ecosystems in western North America due to invasion by plague: Journal of the Idaho Academy of Science, 37, 62-65.

Bland DM, Jarrett CO, Bosio CF, Hinnebusch BJ (2018). Infectious blood source alters early foregut infection and regurgitative transmission of Yersinia pestis by rodent fleas. PLoS Pathogens, 14(1), e1006859.

Boegler KA, Graham CB, Montenieri JA et al. (2012). Evaluation of the infectiousness to mice of soil contaminated with Yersinia pestis-infected blood. Vector-Borne and Zoonotic Diseases, 12(11), 948-52.

Bonnet S, Michelet L, Moutailler S, Cheval J, Hébert C, Vayssier-Taussat M, Eloit M (2014). Identification of parasitic communities within European ticks using next-generation sequencing. PLoS neglected tropical diseases, 8(3). 
Bonvicino CR, Oliveira JA, Cordeiro-Estrela P, D'andrea PS, Almeida AM (2015). A taxonomic update of small mammal plague reservoirs in South America. Vector-Borne and Zoonotic Diseases, 15, 571-579.

Bos KI, Herbig A, Sahl J et al. (2016). Eighteenth century Yersinia pestis genomes reveal the long-term persistence of an historical plague focus. Elife, 5, e12994. https://doi.org/10.7554/eLife.12994.

Brown EM, McTaggart LR, Zhang SX, Low DE, Stevens DA, Richardson SE (2013). Phylogenetic analysis reveals a cryptic species Blastomyces gilchristii, sp. nov. within the human pathogenic fungus Blastomyces dermatitidis. PLoS One, 8(3).

Brunner JL, LoGiudice K, Ostfeld RS (2008). Estimating reservoir competence of Borrelia burgdorferi hosts: prevalence and infectivity, sensitivity, and specificity. Journal of Medical Entomology, 45: 139-147. pmid:18283955.

Burdelov LA (1991). Hostal and functional structure of the Central Asian desert plague focus (on the example of the Pre-Aral area): Abstract. Unpublished Doctoral Thesis in Biological Science. All-Union Anti-plague Research Institute "Microbe”, Saratov. pp. 42.

Burgin CJ, Colella JP, Kahen PL, Upham NS (2018). How many species of mammals are there? Journal of Mammalogy, 99, 1-14

Busch JD, Van Andel R, Stone NE et al. (2013). The innate immune response may be important for surviving plague in wild Gunnison's prairie dogs. Journal of Wildlife Diseases, 49(4), 920-31.

Carmichael AG (2016). Plague persistence in Western Europe: A hypothesis. The Medieval Globe, 1(1), 8.

Caten JL, Kartman L (1968). Human plague in the United States 1900-1966. The Journal of the American Medical Association, 205, 333-336.

Chen GC, Huang HW, Liu ZB (2009). Investigation on plague in Goupitan reservoir region in Guizhou [J]. Chinese Journal of Control of Endemic Diseases, 4.

Chouin G (2018). Reflections on plague in African history (14th-19th C.). Afriques. Débats, méthodes et terrains d'histoire, (09). https://doi.org/10.4000/afriques.2228.

Clover JR, Hofstra TD, Kuluris BG et al. (1989). Serologic evidence of Yersinia pestis infection in small mammals and bears from a temperate rainforest of north coastal California. Journal of Wildlife Diseases, 25, 52-60. 
Colabella C, Corte L, Roscini L et al. (2018). NGS barcode sequencing in taxonomy and diagnostics, an application in "Candida" pathogenic yeasts with a metagenomic perspective. IMA fungus, 9(1), 91-105.

Cui Y, Schmid BV, Cao H et al. (2020). Evolutionary selection of biofilm-mediated extended phenotypes in Yersinia pestis in Response to a Fluctuating Environment. Nature Communications, 11(1), 1-8.

Davis DHS (1953). Plague in South Africa: a study of the epizootic cycle in gerbils (Tatera brantsi) in the northern Orange Free State. Epidemiology \& Infection, 51, 427-449.

Davis S, Begon M, De Bruyn L et al. (2004). Predictive Thresholds for Plague in Kazakhstan. Science, 304(5671), 736-38.

DeWitte SN (2014). Mortality risk and survival in the aftermath of the Medieval black death. PloS One, 9(5), e96513.

Dubyanskiy VM, Yeszhanov AB (2016). Ecology of Yersinia pestis and the epidemiology of plague. In: Yang R, Anisimov A, ed. Yersinia pestis: Retrospective and Perspective. 2016, Springer, Dordrecht, pp. 101-170.

Dunn RR, Davies TJ, Harris NC, Gavin MC (2010). Global drivers of human pathogen richness and prevalence. Proceedings of the Royal Society B: Biological Sciences, 277(1694), 2587-2595. (doi:10.1098/rspb.2010.0340).

Dyer NW, Huffman LE (1999). Plague in free-ranging mammals in western North Dakota. Journal of Wildlife Diseases, 35, 600-602.

Edmunds DR, Williams ES, O'Toole D (2008). Ocular plague (Yersinia pestis) in mule deer (Odocoileus hemionus) from Wyoming and Oregon. Journal of Wildlife Diseases, 44, 983-987.

Eisen RJ, Gage KL (2009). Adaptive strategies of Yersinia pestis to persist during inter-epizootic and epizootic periods. Veterinary Research, 40(2), 1-14.

Eisen RJ, Petersen JM, Higgins CL, Wong D et al. (2008a). Persistence of Yersinia pestis in soil under natural conditions. Emerging Infectious Diseases, 14, 941-943.

Eisen RJ, Vetter SM, Holmes JL, Bearden SW, Montenieri JA, Gage KL (2008b). Source of host blood affects prevalence of infection and bacterial loads of Yersinia pestis in fleas. Journal of Medical Entomology, 45(5), 933-38. 
Emelyanov PF (1974). Surveillance over spatial structure of plague epizooty among Vinogradov's jird. Problems of Particularly Dangerous Infections, 35(1), 15-20.

Fan PF, He K, Chen X et al. (2017). Description of a new species of Hoolock gibbon (Primates: Hylobatidae) based on integrative taxonomy. American Journal of Primatology, 79(5), e22631.

Fan S, Ren H, Wei Y et al. (2018). Next-generation sequencing of the cerebrospinal fluid in the diagnosis of neurobrucellosis. International Journal of Infectious Diseases, 67, 20-24.

Fedorov VN (1944). On mechanism of plague microbe preservation in non-epizootic years. Vestnik mikrob., epidem. i parazitol, 27-39.

Fernandes DLRS, Bezerra MF, da Silva MSB et al. (2020). Rodent Hosts and Flea Vectors in Brazilian Plague Foci: A Review. Integrative zoology, (DOI: 10.1111/17494877.12480).

Fukushima H, Hao Q, Wu K et al. (2001). Yersinia enterocolitica O9 as a possible barrier against $Y$. pestis in natural plague foci in Ningxia, China. Current Microbiology, 42, 1-7.

Gage KL (2010). Factors Affecting the Spread and Maintenance of Plague. In: Almeida AMP, Leal NC, ed. Advances in Yersinia Research. Springer, New York, pp. 79-94.

Gage KL Kosoy MY (2005). Natural history of plague: perspectives from more than a century of research. Annual Review of Entomology, 50, 505-528.

Gratz N (1999). Rodent reservoirs and flea vectors of natural foci of plague. Plague manual: epidemiology, distribution, surveillance and control, 6, 63-96.

Green MH (2018). Putting Africa on the black death map: Narratives from genetics and history.

Afriques. Débats, Méthodes et Terrains D'histoire, 9. http://journals.openedition.org/afriques/2125.

Han BA, Schmidt JP, Bowden SE, Drake JM (2015). Rodent reservoirs of future zoonotic diseases. Proceedings of the National Academy of Sciences, 112, 7039-7044.

Henke SE, Pence DB, Demarais S, Johnson JR (1990). Serologic survey of selected zoonotic disease agents in black-tailed jack rabbits from western Texas. Journal of wildlife diseases, 26, 107-111.

Hinnebusch BJ (2005). The evolution of flea-borne transmission in Yersinia pestis. Current Issues in Molecular Biology, 7, 197-212. 
Hudson BW, Quan SF, Goldenberg MI (1964). Serum antibody responses in a population of Microtus californicus and associated rodent species during and after Pasteur ella pestis epizootics in the San Francisco Bay area. Zoonoses Research, 3, 15-29.

IUCN. The IUCN Red List of Threatened Species. 2019, Available from: https://www.iucnredlist.org/.

Jones SD, Atshabar B, Schmid BV, Zuk M, Amramina A, Stenseth N.C (2019). Living with plague: Lessons from the Soviet Union's antiplague system. Proceedings of the National Academy of Sciences, 116(19), 9155-9163.

Karimi Y (1963). Natural preservation of plague in soil. Bulletin de la Societe de pathologie exotique et de ses filiales, 56, 1183.

Karimova TYu, Neronov VM (2007). The nature plague foci of Palaearctic. Moscow, Nauka.

Keesing F, Belden LK, Daszak P et al. (2010). Impacts of biodiversity on the emergence and transmission of infectious diseases. Nature, 468, 647-652. (doi: 10.1038/nature09575 PMID: 21124449).

Kitchener AC, Breitenmoser-Würsten C et al. (2017). A revised taxonomy of the Felidae: The final report of the Cat Classification Task Force of the IUCN Cat Specialist Group. Cat News.

Klein J-M, Poulet A, Simonkovich E (1975). Observations ecologiques dans une zone enzootique de peste en Mauritanie I. les rongeurs, et en particulier Gerbillus gerbillus Oliver, 1801 (Rodentia, Gerbillinae). Journal of Medical Entomology and Parasitology, 13, 13-28.

Kool JL, Weinstein RA (2005). Risk of person-to-person transmission of pneumonic plague. Clinical Infectious Diseases, 40, 1166-1172. (doi:10.1086/428617).

Kozlov MP, Sultanov GV (2000). Plague. In: Natural focality, epizootology. Makhachkala, 3,pp. 303.

Kryštufek B, Vohralík V (2005). Mammals of Turkey and Cyprus: Rodentia I: Sciuridae, Dipodidae, Gliridae, Arvicolinae. Zgodovinsko društvo za južno Primorsko, Koper.

Kryštufek B, Vohralík V (2012). Taxonomic revision of the Palaearctic rodents (Rodentia): Sciuridae: Xerinae 1 (Eutamias and Spermophilus). Lynx, n. s. (Praha), 43(1-2): 17111. 
Lambin EF, Tran A, Vanwambeke SO, Linard C, Soti V (2010). Pathogenic landscapes: interactions between land, people, disease vectors, and their animal hosts. International Journal of Health Geographics, 9, 1-13. (doi: 10.1186/1476-072X-9-54).

Laudisoit A, Neerinckx S, Makundi RH, Leirs H, Krasnov BR (2009). Are local plague endemicity and ecological characteristics of vectors and reservoirs related? A case study in north-east Tanzania. Current Zoology, 55, 200-211.

Lebedev VS, Bannikova AA, Neumann K, Ushakova MV, Ivanova NV, Surov AV (2018). Molecular phylogenetics and taxonomy of dwarf hamsters Cricetulus Milne-Edwards, 1867 (Cricetidae, Rodentia): description of a new genus and reinstatement of another. Zootaxa, 4387, 331-349.

Lechleitner RR, Kartman L, Goldenberg MI, Hudson BW (1968). An epizootic of plague in Gunnison's prairie dogs (Cynomys gunnisoni) in south-central Colorado. Ecology, 49, 734-743.

Lecompte E, Aplin K, Denys C, Catzeflis F, Chades M, Chevret P (2008). Phylogeny and biogeography of African Murinae based on mitochondrial and nuclear gene sequences, with a new tribal classification of the subfamily. BMC evolutionary Biology, 8(1), 199. (doi:10.1186/1471-2148-8-199).

Lowell JL, Antolin MF, Andersen GL, Hu P, Stokowski RP, Gage KL (2015). Single-Nucleotide Polymorphisms Reveal Spatial Diversity Among Clones of Yersinia pestis During Plague Outbreaks in Colorado and the Western United States. Vector Borne and Zoonotic Diseases, 15(5): 291-302.

Malek MA, Bitam I, Drancourt M (2016). Plague in Arab Maghreb, 1940-2015: A Review. Frontiers in public health, 4, $112 . \quad$ Doi: https://doi.org/10.3389/fpubh.2016.00112.

Malek MA, Bitam I, Levasseur A et al. (2017). Yersinia pestis halotolerance illuminates plague reservoirs. Scientific Reports 7, 40022.

Marshall JD, Ouy DV, Gibson FL, Dung TC, Cavanaugh DC (1967). Ecology of plague in Vietnam: commensal rodents and their fleas. Military Medicine, 132, 896-903.

Martin-Alonso A, Soto M, Foronda P et al. (2014). Bartonella spp. and Yersinia pestis reservoirs, Cusco, Peru. Emerging Infectious Diseases, 20, 1069-1070. 
Matchett MR, Biggins DE, Carlson V et al. (2010). Enzootic plague reduces black-footed ferret (Mustela nigripes) survival in Montana. Vector Borne Zoonotic Diseases, 10, 27-35.

McCauley DJ, Salkeld DJ, Young HS et al. (2015). Effects of land use on plague (Yersinia pestis) activity in rodents in Tanzania. American Journal of Tropical Medicine and Hygiene, 92(4), 776-83. http://dx.doi.org/10.4269/ajtmh.14-0504

McNeill WH (1979). Plagues and peoples, A peregrine book. Vol. 2. Harmondsworth, Penguin.

Meinel DM, Margos G, Konrad R, Krebs S, Blum H, Sing A (2014). Next generation sequencing analysis of nine Corynebacterium ulcerans isolates reveals zoonotic transmission and a novel putative diphtheria toxin-encoding pathogenicity island. Genome Medicine, 6(11), 113.

Migliani R, Ratsitorahina M, Rahalison L (2001). Résurgence de la peste dans le District d'Ikongo à Madagascar en 1998. Bulletin de la Société de pathologie exotique, 94, 115118.

Mollentze N, Streicker DG (2020). Viral zoonotic risk is homogenous among taxonomic orders of mammalian and avian reservoir hosts. Proceedings of the National Academy of Sciences, 117(17), 9423-9430. https://doi.org/10.15845/njsr.v4i0.264.s50.

Moore SM, Monaghan A, Borchet JN et al. (2015). Seasonal fluctuations of small mammal and flea communities in a Ugandan plague focus: evidence to implicate Arvicanthis niloticus and Crocidura spp. as key hosts in Yersinia pestis transmission. Parasites and Vectors, 8, $1-15$.

Namouchi A, Guellil M, Kersten O et al. (2018). Integrative approach using Yersinia pestis genomes to revisit the historical landscape of plague during the Medieval period. Proceedings of the National Academy of Sciences of the United States of America, 115(50), e11790-e11797. https://doi.org/10.1073/pnas.1812865115.

Nelson BC (1980). Plague studies in California - the roles of various species of sylvatic rodents in plague ecology in California. Proceedings of the 9th Vertebrate Pest Conference, Mar 1980. Universty of Nebraska Lincoln.

Nilsson P, Solbakken MH, Schmid BV et al. (2020). The genome of the great gerbil reveals species-specific duplication of an MHCII gene. Genome Biology and Evolution, 12(2), $3832-49$. 
Onishchenko GG, Kutyrev VV (2004). Natural plague foci in the territory of Caucasus, CaspianSea Region, Central Asia, and Siberia. Moscow, Medicine.

Ostfeld RS, Keesing F (2000). Biodiversity series: the function of biodiversity in the ecology of vector-borne zoonotic diseases. Canadian Journal of Zoology, 78, 2061-2078. (doi:10.1139/z00-172).

Pečnikar ŽF, Buzan EV (2014). 20 years since the introduction of DNA barcoding: from theory to application. Journal of Applied Genetics, 55(1), 43-52.

Plourde BT, Burgess TL, Eskew EA, Roth TM., Stephenson N, Foley JE (2017). Are disease reservoirs special? Taxonomic and life history characteristics. PloS one, 12(7), $\mathrm{e} 0180716$.

Poland J, Barnes A (1979). Plague. In: Steele JH ed. CRC Handbook Series in Zoonoses, Section A-Bacterial, Rickettsial, and Mycotic Diseases, vol 1. CRC Press, Boca Raton, pp. 515-597.

Pollitzer R (1960). A review of recent literature on plague. Bulletin of the World Health Organization, 23, 313-400.

Purty RS, Chatterjee S (2016). DNA barcoding: an effective technique in molecular taxonomy. Austin journal of biotechnology \& bioengineering, 3(1), 1059.

Rahelinirina S, Rajerison M, Telfer S, Savin C, Carniel E, Duplantier JM (2017). The Asian house shrew Suncus murinus as a reservoir and source of human outbreaks of plague in Madagascar. PLoS neglected tropical diseases, 11, e0006072.

Ramasindrazana B, Andrianaivoarimanana V, Rakotondramanga JM, Birdsell DN, Ratsitorahina M, Rajerison M (2017). Pneumonic plague transmission, Moramanga, Madagascar, 2015. Emerging infectious diseases, 23, 521.

Ramírez JD, Hernández C, León CM, Ayala MS, Flórez C, González C (2016). Taxonomy, diversity, temporal and geographical distribution of Cutaneous Leishmaniasis in Colombia: A retrospective study. Scientific reports, 6, 28266.

Randremanana R, Andrianaivoarimanana V, Nikolay B et al. (2019). Epidemiological characteristics of an urban plague epidemic in Madagascar, August-November, 2017: An outbreak report. The Lancet Infectious Diseases, 19(5), 537-545. 
Rascovan N, Sjögren KG, Kristiansen K, Nielsen R, Willerslev E, Desnues C, Rasmussen S (2019). Emergence and spread of basal lineages of Yersinia pestis during the Neolithic decline. Cell, 176(1-2), 295-305.

Rasmussen S, Allentoft M, Nielsen K et al. (2015). Early divergent strains of Yersinia pestis in Eurasia 5,000 years ago. Cell, 163(3), 571-582.

Reijniers J, Davis S, Begon M, Heesterbeek JA, Ageyev VS, Leirs H (2012). A curve of thresholds governs plague epizootics in Central Asia. Ecology Letters, 15, 554-560.

Richard V, Riehm JM, Herindrainy P et al. (2015). Pneumonic plague outbreak, northern Madagascar, 2011. Emerging Infectious Diseases, 21, 8-15.

Riehm JM, Tserennorov D, Kiefer D et al. (2011). Yersinia pestis in small rodents, Mongolia. Emerging Infectious Diseases, 17, 1320-1322.

Salkeld D, Stapp P (2006). Seroprevalence rates and transmission of plague (Yersinia pestis) in mammalian carnivores. Vector-Borne \& Zoonotic Diseases, 6, 231-239.

Salkeld DJ, Eisen RJ, Stapp P et al. (2007). The potential role of swift foxes (Vulpes velox) and their fleas in plague outbreaks in prairie dogs. Journal of Wildlife Diseases, 43, 425-431.

Samia NI, Kausrud KL, Heesterbeek H (2011). Dynamics of the plague-wildlife-human system in Central Asia are controlled by two epidemiological thresholds. Proceedings of the National Academy of Sciences, 108, 14527-14532.

Saraev FA, Sklyarenko GP (2012). Materials of landscape-epizootiological zoning of Ural-Emba autonomous plague focus. Quarantine and Zoonotic Infections in Kazakhstan, Almaty, $14-18$.

Sludskyi AA (2014a). The epizootology of the plague (a review of studies and hypotheses). Unoublished report (08.11.2014, № 231), deposited at the Russian Institute for Scientific and Technical Information of Russian Academy of Sciences, , Saratov, 313 pp.

Sludskyi AA (2014b). The list of vertebrates of the world fauna-the hosts of the plague pathogen. Problems of Especially Dangerous Infections, 3, 42-51.

Snall T, O’Hara RB, Ray C, Collinge SK (2008). Climate-driven spatial dynamics of plague among prairie dog colonies. The American Naturalist, 171, 238-248.

Spyrou MA, Keller M, Tukhbatova RI et al. (2019). Phylogeography of the second plague pandemic revealed through analysis of historical Yersinia pestis genomes. Nature Communications, 10(1), 4470. 
Spyrou MA, Tukhbatova RI, Wang CC et al. (2018). Analysis of 3800-year-old Yersinia pestis genomes suggests Bronze Age origin for Bubonic plague. Nature Communications, 9(1), 2234.

Stenseth NC, Atshabar BB, Begon M et al. (2008). Plague: past, present, and future. PLoS Medicine, 5, e3. https://doi.org/10.1371/journal.pmed.0050003.

Sticker G (1908). Abhandlungen Aus Der Seuchengeschichte Und Seuchenlehre. I Band. Die Pest Verlag. Giessen, A. Töpelmann.

Sun Z, Xu L, Schmid BV et al. (2019). Human plague system associated with rodent diversity and other environmental factors. Royal Society Open Science, 6(6), 190216.

Taylor PJ, Denys C, Fenton PD (2019). Taxonomic anarchy or an inconvenient truth for conservation? Accelerated species discovery reveals evolutionary patterns and heightened extinction threat in Afro-Malagasy small mammals. Mammalia, 83(4), 313329.

Tollenaere C, Duplantier JM, Rahalison L, Ranjalahy M, Brouat C (2011). AFLP genome scan in the black rat (Rattus Rattus) from Madagascar: Detecting Genetic Markers Undergoing Plague-Mediated Selection. Molecular Ecology, 20(5), 1026-38.

Tom O (custodian), Dave N (ed) (2019). ITIS Global: The Integrated Taxonomic Information System (version Jun 2017). In: Roskov Y, Ower G, Orrell T, Nicolson D, Bailly N, Kirk PM, Bourgoin T, DeWalt RE, Decock W, Nieukerken E van, Zarucchi J, Penev L, ed. Species 2000 \& ITIS Catalogue of Life, 29th January 2019 [cited 2019; Available from: www.catalogueoflife.org/col.

Trudeau KM, Britten HB, Restani M (2004). Sylvatic plague reduces genetic variability in blacktailed prairie dogs. Journal of Wildlife Diseases,40, 205-211.

Turner RW, Padmowirjono S, Martoprawiro S (1975). Dynamics of the plague transmission cycle in Central Java (ecology of mammalian hosts with special reference to Rattus exulans). Indonesian Bulletin of Health Research, 3(1), 20647.

Twigg GI (1978). The role of rodents in plague dissemination: a worldwide review. Mammal Review, 8, 77-110.

Warsawskiy SN, Kazakevitch VP, Lavrovskii AA (1971). Natural focality of plague in the northern and western Africa. Problems of Particularly Dangerous Infections, 3, 149-159. 
White RJ, Razgour O (2020). Emerging zoonotic diseases originating in mammals: a systematic review of effects of anthropogenic land-use change. Mammal Review, 50,336-352.

WHO. Global distribution of Natural Plague foci (2016); Available from: https://www.who.int/csr/disease/plague/Plague-map-2016.pdf?ua=1.

Wilson DE, Lacher TE, Mittermeier RA (Eds.). (2017). Handbook of the Mammals of the World: Rodents II. Lynx Edicions, Barcelona.

Wilson DE, Mittermeier RA, Ruff S, Martínez-Vilalta A, Cavallini P (Eds.). (2016). Handbook of the Mammals of the World: Lagomorphs and Rodents I. Lynx Edicions, Barcelona, pp, 987.

Woolhouse M, Gaunt E (2007). Ecological origins of novel human pathogens. Critical reviews in microbiology, 33, 231-242.

World Health Organization. (2017). Plague outbreak Madagascar: External situation report 14.

Xu L, Schmid BV, Liu J, Si X (2015). The trophic responses of two different rodent-vector plague systems to climate change. Proceedings of the Royal Society B: Biological Sciences, 282(1800), 20141846.

$\mathrm{Xu}$ L, Stige LC, Leirs H et al. (2019). Historical and genomic data reveal the influencing factors on global transmission velocity of plague during the third pandemic. Proceedings of the National Academy of Sciences, 116(24), 11833-11838.

Zachos FE, Apollonio M, Bärmann EV (2013). Species inflation and taxonomic artefacts-A critical comment on recent trends in mammalian classification. Mammalian Biology, 78, $1-6$.

Zachos FE, Christidis L, Garnett ST (2019). Mammalian species and the twofold nature of taxonomy: a comment on Taylor et al. 2019. Mammalia, 84(1), 1-5.

Zeppelini CG, de Almeida AMP, Cordeiro-Estrela P (2016). Zoonoses as ecological entities: a case review of plague. PLoS neglected tropical diseases, 10(10):e0004949.

Ziwa MH, Matee MI, Hang'ombe BM, Lyamuya EF, Kilonzo BS (2013). Plague in Tanzania: an overview. Tanzania Journal of Health Research, 15, doi: 10.4314/thrb.v15i4.7. 
Table 1. Observed representation of mammalian orders among reservoirs (in percentage) versus expected. The expected values represent the amount of species per order that would be identified as reservoirs if they were found as a reservoir host in the same proportions as they are all mammals. Positive residuals represent more reservoir species than expected by chance. Negative residuals represent fewer reservoir species than expected by chance.

\begin{tabular}{lccccc}
\hline $\begin{array}{l}\text { Mammalian } \\
\text { orders }\end{array}$ & $\begin{array}{c}\text { No. of } \\
\text { species }\end{array}$ & $\begin{array}{c}\text { No. of } \\
\text { identified } \\
\text { reservoirs }\end{array}$ & $\begin{array}{c}\text { Observed } \\
(\%)\end{array}$ & Expected (\%) & $\begin{array}{c}\text { Residuals } \\
\text { (O-E) }\end{array}$ \\
\hline Scandentia & 24 & 1 & 0.2849003 & 0.505689001 & -0.2208 \\
\hline Hyracoidea & 5 & 1 & 0.2849003 & 0.105351875 & 0.1795 \\
\hline Afrosoricida & 55 & 1 & 0.2849003 & 1.158870628 & -0.8740 \\
\hline Didelphimorphia & 111 & 2 & 0.56980057 & 2.338811631 & -1.7690 \\
\hline Primates & 518 & 2 & 0.56980057 & 10.91445428 & -10.3447 \\
\hline Artiodactyla & 551 & 7 & 1.994301994 & 11.60977665 & -9.6155 \\
\hline Eulipotyphla & 527 & 13 & 3.703703704 & 11.10408765 & -7.4004 \\
\hline Lagomorpha & 98 & 14 & 3.988603989 & 2.064896755 & 1.9237 \\
\hline Carnivora & 305 & 31 & 8.831908832 & 6.426464391 & 2.4054 \\
\hline Rodentia & 2552 & 279 & 79.48717949 & 53.77159713 & 25.7156 \\
\hline total & $\mathbf{4 7 4 6}$ & $\mathbf{3 5 1}$ & $\mathbf{1 0 0}$ & $\mathbf{1 0 0}$ & $\mathbf{0}$ \\
\hline
\end{tabular}


Table 2. Main reservoir species in different foci worldwide. Reservoirs differ considerably from one focus to another. Resistant species are shown in bold.

\begin{tabular}{|c|c|c|}
\hline Region & Reservoir species & Reference \\
\hline \multicolumn{3}{|l|}{ Former Soviet Union: } \\
\hline Pre-Caspian region & Spermophilus pygmaeus & Gratz (1999), Onishchenko \& \\
\hline Sandy areas & Meriones meridianus, $M$. & Kutyrev (2004) \\
\hline & tamariscinus & \\
\hline Central Asian & Rhombomys opimus, Meriones & \\
\hline & libycus & \\
\hline Central & Marmota baibacina, M. caudata, & \\
\hline highlands & Microtus juldaschi & \\
\hline Transcaucasian & Meriones libycus, etc. & \\
\hline area & & \\
\hline High-mountain & Spermophilus musicus, Microtus cfr. & \\
\hline territories & arvalis & \\
\hline Caucasus & & \\
\hline \multicolumn{3}{|l|}{ Trans-Caucasia } \\
\hline Low-mountain & Meriones vinogradovi, M. libycus & \\
\hline \multicolumn{3}{|l|}{ Trans-Caucasia } \\
\hline Transbaikalia & Marmota sibirica, Spermophilus & \\
\hline focus & dauricus & \\
\hline \multirow[t]{2}{*}{ Altai highlands } & Marmota baibacina, Urocitellus & \\
\hline & undulatus, Ochotona pallasi & \\
\hline \multirow{5}{*}{$\begin{array}{l}\text { Southeast Asia and the } \\
\text { western Pacific }\end{array}$} & Bandicota bengalensis, Millardia & Pollitzer (1960), Gratz (1999), \\
\hline & meltada, Tatera indica, Rattus & Sludskyi (2014b) \\
\hline & norvegicus, $R$. rattus, $R$. rattus & \\
\hline & diardii, Suncus murinus, Rattus & \\
\hline & exulans & \\
\hline \multicolumn{3}{|l|}{$\begin{array}{l}\text { Plague foci } \\
\text { southwestern Asia: }\end{array}$} \\
\hline \multirow[t]{2}{*}{ Iran } & Meriones persicus, M. libycus, $M$. & Baltazard et al. $(1952,1960)$ \\
\hline & tristrami, $M$. vinogradovi & Gratz (1999) \\
\hline Africa & Arvicanthis spp. (A. niloticus, etc.), & Pollitzer (1960), Gratz (1999), \\
\hline
\end{tabular}


Gerbilliscus brantsii, Otomys

irroratus, Mastomys natalensis,

Mastomys coucha, Rattus rattus, $R$.

norvegicus, Meriones shawi, $M$.

libycus, Suncus murinus
Malek et al. (2016), Moore et

al. (2015).

\begin{tabular}{|c|c|c|}
\hline \multicolumn{3}{|l|}{ America: } \\
\hline $\begin{array}{l}\text { North America } \\
\text { (USA) }\end{array}$ & $\begin{array}{l}\text { Cynomys gunnisoni, Otospermophilus } \\
\text { variegatus, Microtus californicus, } \\
\text { Peromyscus spp. (P. californicus, } P \text {. } \\
\text { maniculatus, etc.) }\end{array}$ & Pollitzer (1960), Gratz (1999) \\
\hline Mexico & Cynomys mexicanus & Pollitzer (1960) \\
\hline South America & $\begin{array}{l}\text { Oligoryzomys spp., Calomys spp., } \\
\text { Necromys lasiurus, Sciurus } \\
\text { stramineus, Akodon orophilus, } \\
\text { Aegialomys xanthaeolus, Sylvilagus } \\
\text { brasiliensis, Rattus rattus, Galea } \\
\text { spixii }\end{array}$ & $\begin{array}{l}\text { Pollitzer (1960), Bonvicino et } \\
\text { al. (2015) }\end{array}$ \\
\hline Pacific coast & $\begin{array}{l}\text { Otospermophilus beechey, Neotamias } \\
\text { spp., Callospermophilus lateralis }\end{array}$ & Gratz (1999) \\
\hline
\end{tabular}




\section{Figure Caption:}

Figure 1. Global distribution of natural plague foci as of March 2016, based on the historical data and current information (modified after the WHO 2016).

Figure 2. Geographic distribution of the number of plague hosts around the world at the spatial resolution of 0.5 arc degree and based on distributional ranges of 345 hosts in the IUCN Red List of Threatened Species. Maps for a further 10 species were not available at the desired resolution. For a complete list of 355 hosts see the Appendix.

Figure 3. Geographic distribution of the main reservoir species ( 70 species) in different foci around the world at the spatial resolution of 0.5 arc degree. 